\title{
Internationalization strategies of hidden champions: lessons from Germany
}

\author{
David B. Audretsch \\ School of Public and Environmental Analysis, Indiana University, \\ Bloomington, Indiana, USA, and \\ Erik E. Lehmann and Julian Schenkenhofer \\ Faculty of Business and Economics, University of Augsburg, Augsburg, Germany
}

\begin{abstract}
Purpose - In contrast to the predictions from the family business and the small- and medium-sized enterprise internationalization literatures, Hidden Champions are world-market leaders exhibiting a high share of exports. The purpose of this study is to analyze their strategy of internationalization of Hidden Champions in Germany and find that the international success and strong, sustained performance emanates from their product type, enabling to successfully pursue a niche strategy for differentiated premium products.

Design/methodology/approach - The authors first conceptually explore how Hidden Champions pursue strategic internationalization, and then analyze a sample of $N=2,690$ Hidden Champions to examine why Germany has been able to generate the highest per capita share of Hidden Champions in the world.

Findings - The study finds that on both a micro and macro level, the strong and sustained performance of Hidden Champions is driven by product type and quality strategies. Niche strategies for a knowledgeintensive, technological product enable the firm to lock-in customers. However, to safeguard the internalization of highly specific quasi-rents, Hidden Champions enter foreign markets through fully owned subsidiaries, retaining control and residual property rights. The second finding of this paper is that Germany has succeeded in deploying its high level of human capital into the Mittelstand through highly skilled workers.
\end{abstract}

Research limitations/implications - Unfortunately, no micro-level panel data are available. Still macro-level data beginning in the nineteenth century provide strong empirical support for the hypothesized causality.

Originality/value - This is the first paper to link the strong and sustained export performance of Germany to the Hidden Champions by examining the origins of the German Mittelstand model, dating back to the social, political and economic developments of nineteenth century.

Keywords Export, Internationalization, Macroeconomic history, Mittelstand, Niche strategy

Paper type Research paper

\section{Introduction}

The model of the German Mittelstand is frequently characterized as the backbone of the German economy. The stability and resilience of Germany in the wake of the subprime mortgage crisis of 2008 and European sovereign debt crisis in 2010 was at least partially attributed to the Mittelstand. Because of its now celebrated contribution to the strong German economic performance over the past 15 years, the Mittelstand has received global attention from thought leaders in policy and business.

It is well documented that the German Mittelstand has performed very well, enabling Germany to stay competitive in high paying manufacturing, which in turn has maintained 
and even enhanced the prosperity of rural regions as well as cities (Audretsch and Lehmann, 2016; Venohr and Meyer, 2007). The Mittelstand is generally considered to refer to smalland medium-sized enterprises (SMEs) in Germany. As the Wall Street Journal puts it in a recent headline, "The Engines of Growth: Forget the big global brands. Germany's economy is powered by a legion of smaller companies" (Blackstone and Fuhrmans, 2011).

Similarly, The Economist observes, "Most countries want a Mittelstand like Germany's. It's not so easy to copy". (The Economist, 2014) One reason why generating Mittelstand companies outside of Germany remains elusive is that it is not just about firm size. The common misconception about the Mittelstand is that it refers to SMEs in Germany. In fact, that is not true. There are between six and 14 characteristics distinguishing a Mittelstand company, ranging from small size to governance (family ownership), human resource relations, linkages to the local community, finance and long-term orientation, among other things. Firm size, i.e. being classified as an SME, is just one among multiple key salient characteristics (Audretsch and Lehmann, 2016; Welter et al., 2016).

A particularly striking feature of the Mittelstand, which stands in contrast to SMEs in other OECD countries, is the strong performance in exports and internationalization, especially in manufacturing (Venohr and Meyer, 2007).

The Mittelstand is also coveted because it generates what has been termed as "Hidden Champions". Hidden Champions are a subgroup of such Mittelstand firms and world market leaders of niche products. High export shares are a key element of their strategy fueling their strong and sustained performance (Blackburn et al., 2001; Yoon, 2013; Witt and Carr, 2014; Schlepphorst et al., 2016). Simon (1996) has identified the Hidden Champions and finds that they are not restricted to Germany. However, a spatial analysis of the geographic distribution reveals a high share to be located in Germany. Thus, there is clearly a link between the underlying model of the German Mittelstand and the strong internationalization performance of German Hidden Champions.

Using the specific example of Germany, this study analyzes their strategy of internationalization and finds that the international success and strong, sustained performance emanate from their product type, which enables them to successfully pursue a niche strategy for differentiated premium products. We evaluate these arguments using a sample of 2690 Hidden Champions, of which a majority come from Germany.

We contribute to research on the role of SMEs in internationalization (Audretsch $e$ al., 1999; Coviello and McAuley, 1999; Westhead et al., 2001; Francioni et al., 2016; Fariborzi and Keyhani, 2017) and, in particular, to the special case of the German Mittelstand model in achieving a strong and sustained economic performance through internationalization. It is not surprising that, subsequent to its recovery from the Second World War, German exports soared to unprecedented levels (Audretsch and Lehmann, 2016). However, the extant literature analyzing the strong German export performance typically only starts with the Wirtschaftswunder in the late 1950s. Such studies have generally failed to incorporate the origin of German export and Mittelstand success, which dates back much earlier. Germany's industrialization in the middle and second half of the nineteenth century and its transition from an agrarian to an industrial economy coincides with the birth of most Hidden Champions and their global dominance in the relevant product niches. A key and novel contribution made by this study is to identify the key strategies of German Hidden Champions in developing and deploying high levels of human capital and in particular skilled labor, as well as a high degree of vertical integration when entering new markets. Access to highly skilled labor was facilitated by the development of the German vocational educational system along with spillovers from a myriad of supporting institutions designed to provide knowledge and technology to the Mittelstand. 
This paper is organized as follows. Section 2 provides an analysis of Mittelstand internationalization strategies revolving around exports and a high number of subsidiaries located in foreign countries, which is subsequently analyzed through lens of property rights theory to develop several main hypotheses linking strategies for product type and product quality to export performance. Using a large global data base consisting of 2,690 Hidden Champions spanning a broad spectrum of national contexts, these hypotheses are then subjected to empirical scrutiny in Section 3. In Section 4, the underlying reasons why the home country of Germany bestows a strong internationalization performance for Hidden Champions are addressed. A summary and conclusions are provided in the final section. In particular, this paper finds that the strong and sustained export performance of Hidden Champions is not only attributable to the types of products sold but also the high product quality combined with a high degree of vertical forward integration.

\section{Hidden champions and their strategy of internationalization}

Starting in the 1990s, Simon (2009) tried to unravel the secrets of the skyrocketing German export success. In doing so, he discovered a specific subgroup of German SMEs, which he attributed to generating a great share of Germany's impressive export performance. Hidden Champions are defined by Simon (2009) applying the following criteria:

- the Hidden Champion is ranked among the top three leaders in the world share of the relevant product market or has the highest market share on the continent of the home country;

- revenues do not exceed $\$ 4 \mathrm{bn}$; and

- there is a low brand awareness of the company and its products.

The strong export performance of Hidden Champions is difficult to reconcile with the academic research and literature on SME and family business internationalization. The conclusion reached in most studies is that firm size is directly related to internationalization and, in particular, export performance (Bonaccorsi, 1992; Chetty and Hamilton, 1993). In particular, Fernández and Nieto (2005), as well as Graves and Thomas (2008) find that the governance mode of a family owned and/or managed business has a lower propensity to engage in export activities. Internationalization was viewed by an earlier literature as exclusively falling within the domain of large corporations sufficiently equipped with the requisite organizational slack (Bourgeois, 1981). According to this view, larger firms can leverage their resource base to invest in infrastructure facilitating access to foreign markets. The organizational slack is needed to overcome country-specific barriers to entry.

Moreover, Harris et al. (1994) concluded that family businesses internationalize over a stage approach of internationalization. Vahlne and Johanson (1977) similarly found that the process of family business internationalization over these different stages is influenced by the psychic distance to the particular foreign market. The risk-aversion and reluctance to grow aggressively beyond national borders found to characterize family business (GómezMejía et al., 2007) impedes internationalization. Rather than a strategic priority on internationalization, family business has instead appeared to have a higher strategic priority on responsibilities to the local community, such as maintaining employment, as being crucial for a well-known family firm name, so that the managers of family firms "consider themselves as stewards of the family" (Graves and Thomas, 2008, p. 163). The strategic priorities of family and local community over growth and internationalization are consistent with the low propensity for family business to engage in trans-national activities (Zahra, 2003). However, Hidden Champions are different and pose an anomaly to the literatures on 
SMEs, family business and internationalization. As Simon (2009) finds, the mean export share of the Hidden Champions is 61.5 per cent.

In his seminal work on generic Competitive Strategies, Porter (1980) analyzes organizational strategies available to attain a sustainable competitive advantage. In particular, Porter (1980) distinguished among cost leadership, product differentiation and a product niche strategy. The first strategy, cost leadership, enables the firm to exploit advantages emanating from product standardization, mass markets and scaling fixed costs. The cost leadership strategy maximizes profits by generating a large volume of sales with low profit margins.

By contrast, the product differentiation strategy is based on a high-quality product, which reduces the elasticity of demand by raising the customer willingness to pay, with the goal of creating a monopolistic market. Finally, the niche strategy aims at a small segment of few customers, where the product is tailored to the specific and specialized needs of the particular customer (Stanton et al., 1991). Hidden Champions typically deploy a niche market strategy of premium quality products. Entering new markets is an essential prerequisite for them to grow. Thus, their model of exporting and internationalization emulates the model of a niche strategy.

Being heavily specialized in a particular product niche, the Hidden Champion cannot generate a strong and sustained performance by remaining restricted to the domestic market. Scaling their business would be impossible to achieve solely within their narrow product niche in the home domestic geographic market. Entering new geographic markets through internationalization is their key strategy to attaining and sustaining a strong performance. In addition, their international activities can act to preempt the long-run entry of potential competitors, as their dominating role of an incumbent is not guaranteed (Venohr and Meyer, 2007), though Hidden Champions operate in quasi-monopolistic markets.

Being a product leader dominating the niche implies a presence in other geographic or national markets, which essentially happens on a global scale. Simon (2009) emphasizes that internationalization requires certain attitudes as an antecedent. In particular, an openness to learning about and understanding other national contexts is essential to discover internationalization opportunities. According to Simon, cultural openness and tolerance enable Hidden Champions to embrace foreign cultural patters of communications and doing business (Nummela et al., 2004; Levy et al., 2007; Ramsey et al., 2016). Though a number of studies address the impact of a global mindset, the current study instead posits that the internationalization performance of Hidden Champions may have more to do with the niche product and market strategies and less to do with the boldness of decision-makers.

Because of the key role played by their internationalization strategy, Hidden Champions need to develop a complementary internal skill base. Developing a company image as a global market leader facilitates attracting, motivating and maintaining highly skilled workers. Workers employed at a Hidden Champion take pride in their work and contribution to a world-class leader. Thus, world-market leadership is an openly stated goal of many Hidden Champions and constitutes a core company value. With smaller organizations simplifying internal integration processes (Fearon, 1999), Hidden Champions' managers and leaders find it easier to shape both the company culture and organizational self-image as a market-leader than do other firms in the industry.

Venohr and Meyer (2007) similarly point out that advances in transportation, information and communication technologies, which have facilitated globalization, are also conducive to the small firm niche strategy. These developments have mitigated the barriers and obstacles to internationalization that in an earlier era impeded the international 
activities of small firms. The niche dominated by Hidden Champions is typically sufficiently small to be attractive to large corporations.

In addition, the large and bureaucratic vertical hierarchically organized companies typically do not have a competitive advantage in a niche characterized by dynamism and close relationships with customers. Using survey-based data, Simon (2009) found that the share of employees having frequent interactions with customers is between one-quarter and one-half for Hidden Champions, compared with 5 to 10 per cent for large corporations. Because Hidden Champions often foster incremental rather than radical innovation, their competitive advantage derives from the unique and customized needs of individual clients. Thus, to meet these specialized and individualized customer demands, technological advancement along with high R\&D investments play a key role (Zuchella and Palamara, 2006).

Hidden Champions generate revenue through high profit margins on a relatively low volume of sales. By contrast, the large, mass market counterparts tend to achieve revenues on lower profit margins for a high volume of sales (Kotler, 1991). Dalgic and Leeuw (1994) suggest that while mass marketing firms tend to be centralized and bureaucratic, the niche strategy of smaller firms is more conducive to decentralization and participative decisionmaking processes. This in turn suggests that the flatter an organizational hierarchy and the more decentralized authority control, the higher are the interaction rates between two entities capitalizing on more points of contact. If more people are involved in exchanging information, the better a seller is able to satisfy the buyer with a highly specialized and knowledge-intense product. An important implication is that the hierarchical and centralized organization of large corporations impedes direct and frequent interactions at the important operational base of engineers on-site (McDonald et al., 2008). Thus, as niches emerge to meet unique customer needs requiring product specialization, the organization type best suited for meeting those needs will prevail - in this case the Hidden Champion.

\section{FDI and the theory of property rights}

Hidden Champions enter new markets through both direct export and a remarkably high number of subsidiaries. On average, a Hidden Champion owns a high number of (almost) completely owned foreign subsidiaries, 24. Among them, 16 are distinguished sale and service organizations and with eight of them being involved in both manufacturing and sales (Simon, 2009). Remaining independent of third parties (through indirect export or licensing) enables them to retain the unequivocal rights of control. Hidden Champions strategically position themselves along the make or buy continuum toward the former, enabling them to attain a high degree of value added. In light of the ownership advantages in the eclectic model of internationalization (Dunning, 1988), licensing and indirect export present a second best for Hidden Champions against the backdrop of the severe threat of knowledge drain and soaring costs of coordination and contracting.

In addition, foreign subsidiaries facilitate close customer relationships for a Hidden Champion, while at the same time demonstrating a sizeable presence. Internationalization is a key component of the Hidden Champion strategy, as evidenced by the high share of Hidden Champions, 74.4 per cent, which engage in export activities during their startup phase. Similarly, 33.9 per cent of the Hidden Champions opened at least one foreign subsidiary just subsequent to their startup (Simon, 2009). By contrast, the stage models of internationalization, such as Johanson and Vahlne's (1977), imply that internationalization activities would play only a tangential role for Hidden Champions (Verbeke and Yuan, 2016). Zuchella and Palamara (2006) similarly suggest that niche firms show a higher propensity to internationalize rather simultaneously than serially, because they are less 
hampered by geographic or psychic distance than are their large-scale mass market counterparts. This again reflects the general view prevalent in the literature suggesting that a global mindset is not essential for a firm pursuing a niche strategy - which is contrary to the strong internationalization exhibited by the Hidden Champions.

The lens provided by the causal mechanisms of the theory of the firm illuminates why the strategy of developing foreign subsidiaries is so important to Hidden Champions. In particular, this theory explains why integration of transactions within the controllable scope of the boundaries of the firm can be superior to the market and its price mechanism (Demsetz, 1988). Holmström and Tirole (1989) emphasize the key role played by the boundaries of the firm and degree of vertical integration, which was subsequently linked to foreign direct investment (FDI) as a strategy for integrating foreign business into firm hierarchy (Nunn and Trefler, 2008; Antràs and Helpman, 2004). Grossman and Hart (1986) posited that direct ownership over assets contains residual rights of control and thus lessens the scope of action for the integrated party to be misused opportunistically in the light of emerging contingencies from incomplete contracting. Direct ownership therefore restricts the scope of a transaction for a partner's moral hazard. The welfare maximizing optimum in a first best scenario implies that a party $A$, with a production function with high investment specificity, has the security of full residual rights from its investments. If not vertically integrated, both parties bargain ex post regarding the return of surplus. Assuming a Nash equilibrium from the bargain only grants them half the benefit from their investments and anticipating this results in both parties, $A$ and $B$, to underinvest. Ownership rights should thus guard investments for the party contributing more to the value of the transaction. Assuming that $A$ is the residual claimant, none of the possible ex post opportunistic actions of transaction partner $B$ lowers the return of $A$ 's ex ante specific investments. This only is possible if $A$ is granted the viable property rights over assets and thus possesses a natural source of negotiation power.

However, what generates asset specificity between a Hidden Champion's headquarters in the home country and the transaction partners? Analyzing the determinants comprising the difference between first and second-best solution for the transaction yields insights into why Hidden Champions choose to vertically integrate over market solutions, such as intermediary-based export or licensing.

The striking characteristic generating market advantages emanates from the product strategies of a Hidden Champion. The business model revolves around a deep focus and high-end specialization targeting a highly knowledge-intensive product closely linked to R\&D and patenting. Employees are trained accordingly and show remarkably low rates of turnover. Simon (2009) estimates the annual employee turnover rate at 2.7 per cent for Hidden Champions, compared to the average for German firms of 7.3 per cent. The ability of the Hidden Champions to retain its highly skilled workforce serves to enhance the incentive to invest in firm-specific human capital (Becker, 1964). The knowledge-intensity of the Hidden Champions generates knowledge assets, which are sticky in nature and have a firm specificity, which is conducive to achieving and sustaining a competitive advantage within the niche market.

Building on Coase's insights for the role played by transaction costs, Williamson (1975) explains how the cost of acquiring knowledge for ordinary distributors, courts or other third parties is prohibitively high when it is based on tacit and customized knowledge about the product and production process. This renders arms-length contracts as inefficient and results in underinvestment owing to high levels of uncertainty associated with legal protection. 
When designing the boundaries of an organization, the foreign integration model is mainly driven by the concept of headquarter intensity (Nunn and Trefler, 2008; Antràs and Helpman, 2004). Hidden Champions own an average of 24 subsidiaries, of which only a mean of eight are engaged in manufacturing. Thus, the bulk of manufacturing by the Hidden Champions is in the home country, which facilitates monitoring. As Venohr and Meyer (2007) point out, Hidden Champions mostly use productivity gains in manufacturing to remain competitive vis-a-vis lower labor costs of manufacturing abroad. The overseas subsidiaries tend to provide benefits as sole sale and service partners. Thus, the overseas integration for Hidden Champions safeguards against internalizing quasi-rents being contested within market-based relationships.

Antràs and Chor (2013) introduce a property-rights model of the firm analyzing how to allocate control of assets given sequenced stages of contracting between a final-good producer and a supplier. In their scenario, they investigate the acquisition of customized components of high investment specificity. Headquarter intensity, as a proxy for investment specificity, is typically measured by the intensity of human capital, physical capital, R\&D and materials, reflecting intrafirm trade. Another factor favoring foreign integration as measure of investment specificity is technological intensity, as used by Acemoglu et al. (2010), Lileeva and Van Biesebroeck (2008). Simon (2009) has attributed all of these characteristics contributing to the strong performance and internationalization of Hidden Champions, which therefore underlines their high headquarter intensity involving a high degree of value added - thus calling for vertical forward integration.

\section{Empirical evidence}

This paper further sheds light on the determinants of internalization by integrating the characterization of the Hidden Champions introduced by Simon (2009) with the findings from the export determinants literature. In particular, a rich extant literature has generated a plethora of findings highlighting the roles played by product quality and industry type as determinants of export success. Therefore, what Hidden Champions produce seems to be a key to understanding their internationalization strategy and success. Reviewing studies analyzing the determinants of export success, Zou and Stan (1998) categorize this field of literature according to the dimensions of strategically controllable and uncontrollable factors. Leonidou et al. (2002) distinguish among managerial, organizational, environmental, marketing strategy and export target-related factors. Aaby and Slater (1989) classify studies and findings according to internal (firm characteristics, competencies, marketing strategy) and external (environment) determinants.

We instead suggest categorizing the extant literature according to the dimensions of factors especially relevant for mass markets standardization, mass markets customization and niche markets, as many of the determinants of export already substantiated hold only when belonging to one of these categories. Their sign and causal explanations often change with the scope of their market. Among the many factors analyzed, firm size emerges as one of the most highlighted focal points of these studies. The empirical evidence consistently finds that firm size is positively related to export performance for mass markets but negatively for niche markets (Bonaccorsi, 1992; Audretsch et al., 1999). The same findings hold for the literature on prizes, which analyzes how firms compete over low prizes in mass markets, while niches allow for premium products of higher margined products (Kirpalani and MacIntosh, 1980). Management capabilities seem to more important in mass markets, because more competition demands a higher rate of decisions to be made (Cavusgil and Zou, 1994). The niche and its quasi-monopolistic structure provides a source of convenient competitive advantage, therewith reducing the leverage of a single manager. 
Product adaption has also been analyzed frequently. The findings prevalent in the literature suggest that mass-customization is more conducive to product adaption (Leonidou et al., 2002; Lages et al., 2009), because niche products often do not adhere to foreign local cultural tastes and preferences but rather follow a technological fit. Top management commitment as a driver of internationalization has been found to be more important in mass markets (Koed Madsen, 1989), as niches require entry into new geographic markets as a precondition for growth. Acquired export experience has been tested vigorously in a number of studies and proves less salient for niches (Katsikeas and Morgan, 1994; Leonidou, 1995), where managers rather follow a simultaneous approach (Cavusgil, 1984), with stage approaches being linked to mass marketing strategies.

Studies have found that product strength enables the firm to prevail against competition in mass markets (Burton and Schlegelmilch, 1987) or for deterring potential competitors in niche markets. In this regard, product strength, in terms of product uniqueness and patents, has been found to have a positive and significant impact on export performance (Michell, 1979; Zou and Stan, 1998; Julian, 2003; Morgan et al., 2004). In terms of product design, the mass-niche dichotomy holds again (Cunningham and Spiegel, 1971). Product quality has also been found to be positively related to higher export rates (Leonidou et al., 2002).

In addition to product quality, the type of product and the industry has been found to be critical to export performance. A higher degree of industry technological sophistication is positively related to the propensity to export (Holzmuller and Kasper, 1991; Cavusgil and Zou, 1994; Majocchi, Bacchiocchi and Mayrhofer, 2005). Lages et al. (2009) introduced a conceptual framework linking the antecedents of quality and innovation to export success. They center their analysis on the impact of firm-specific quality capabilities on employee involvement, customer focus and employee quality training, all of which are consistent with Simon's (2009) characterization of Hidden Champions.

\section{Germany as home country}

The final part of this paper extends the work of Audretsch and Lehmann (2016) and in particular Simon $(2009,2012)$, to explain why Germany is particularly hospitable to both a strong Mittelstand and Hidden Champions. As Simon (2012) shows, Germany serves as the home country to the largest share of Hidden Champions. We posit that the underlying causal mechanisms are attributable to institutions and polices, with deep historical roots. Recent literatures have characterized what is terms as national systems of innovation (Nelson, 1993; Acs et al., 2017) and national systems of entrepreneurship (Acs et al., 2016). Both literatures focus on country-specific institutions and policies shaping the competitive advantage of firms and in the case of the latter, entrepreneurial firms.

The institutions and policies of Germany are compatible with and conducive to producing not just high quality premium goods but also those addressing a niche demand. As Simon (2012) explains, there a strong potential for exporting such goods, with a high worldwide demand, particularly in growing economies (Simon, 2012). Prior to 2009, Germany was the perennial global leader in exports, before being relegated by China to second place.

Figure 1 shows that based on a worldwide sample of 2,690 Hidden Champions, the clear majority reside in Germany as the home country. As explained above, Hidden Champions are generally high performing Mittelstand companies. Germany's overall SME sector exhibits a strong export performance within the OECD, as Figure 2 shows. The data in Figure 2 are in terms of billions of US dollars and refer to firms between 50-250 employees. This evidence is consistent with the hypothesis positing a strong German Mittelstand internationalization performance. 
Figure 1.

Number of hidden champions per 10 million inhabitants

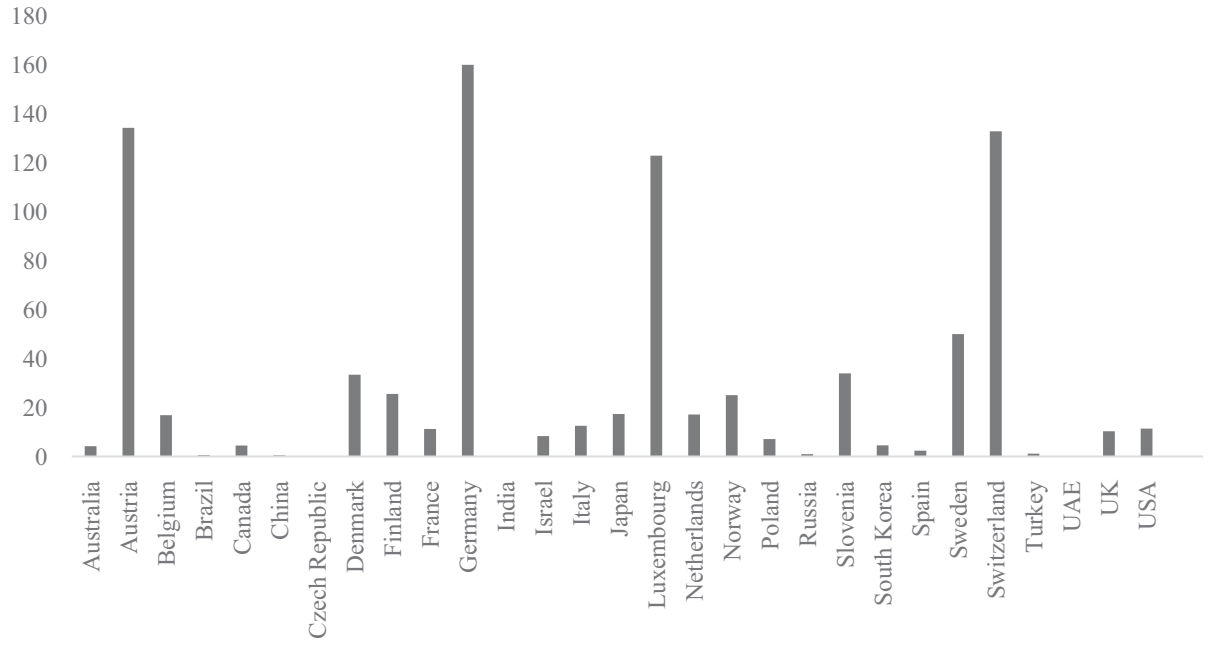

Source: Own depiction, data retrieved from Rammer and Spielkamp (2015)
Figure 2.

Export share of SMEs by GDP per capita (2010-2014)

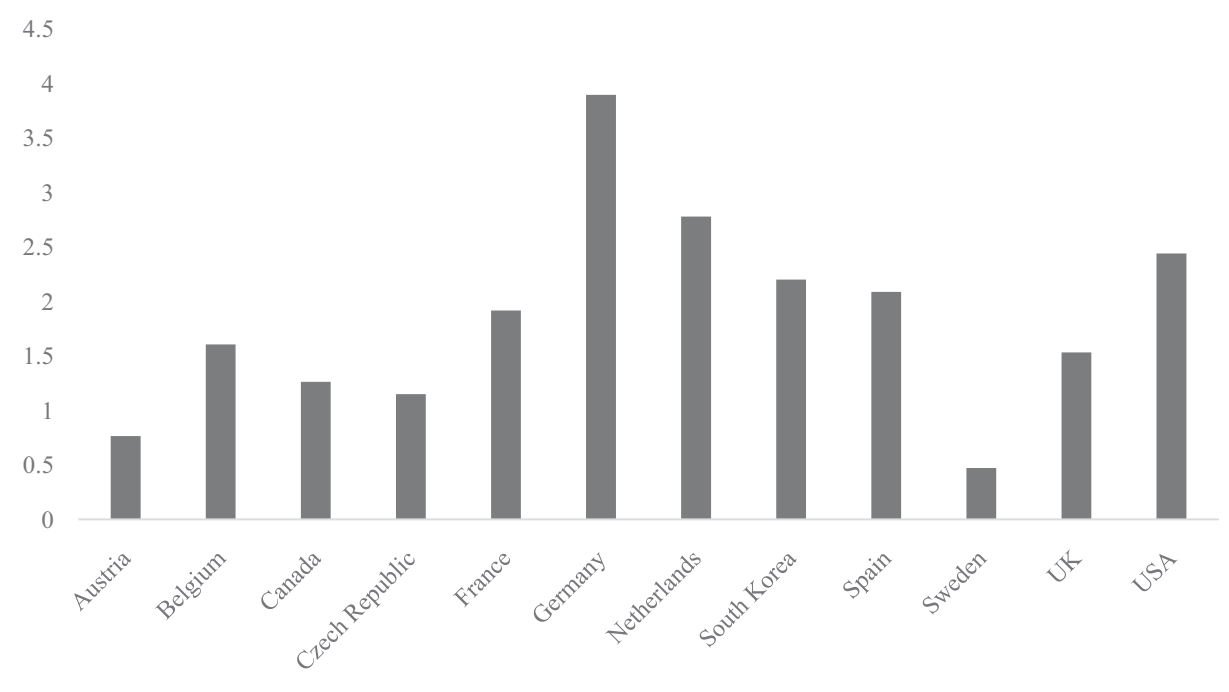

Source: Own depiction, data retrieved from OECD (2017)

In light of Germany's late industrialization as a belated nation (Berger, 1995; Weisbrod, 1996), the origin of German (and thus German Hidden Champion) product strength dates back to Germany's transition from an agrarian to an industrial economy. Figure 3 illustrates this epochal shift. Within a time span of a half century (ca. 1850-1910), rural Germany shifted from producing mainly linen, wool and corn to become the largest world economic power, reflecting a "coalition of rye and iron" (Torp, 2010, p. 401) before First World War.[1] 


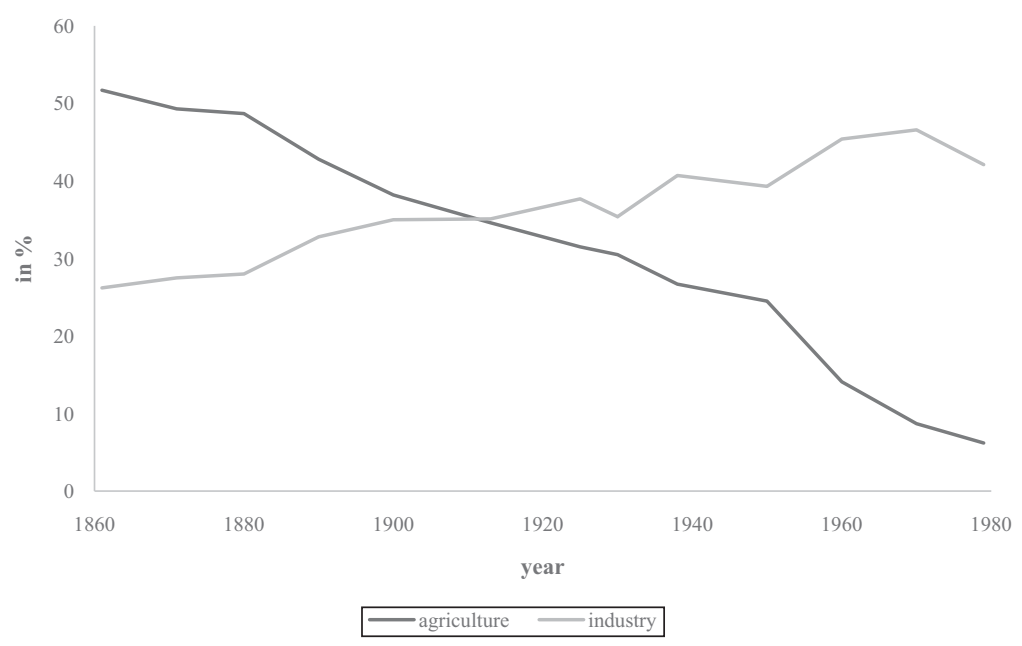

Source: Own depiction following Sommariva and Tullio (1987, p. 27), data retrieved from Hoffmann (1965)
Figure 3.

Employment by sector $1861-1979(\%$ of total employment)

How was that possible? The source of German export success, along with its global reputation and brand for goods Made in Germany and the associated phenomenon of Mittelstand world market leaders can be traced back to this sectoral transformation.

Contemporary German export performance is generally attributed to developments over the past two decades by the extant literature. As recently as the turn of this century Germany had been written off as the sick man of Europe. The more historical accounts of the strong German internationalization performance found in the literature typically start with Stunde Null at the close of the Second World War and the subsequent Wirtschaftswunder of the late 1950s (Venohr and Meyer, 2007; Audretsch and Lehmann, 2016). While such explanatory theories make important contributions to understanding the strong and sustained internationalization performance of the German Hidden Champions as well as the broader Mittelstand, they clearly fail to recognize that the foundations of the Wirtschaftswunder were cemented long before both the world wars of the twentieth century. In fact, they date back to the time when the German Reich was founded in 1871. Thus, the roots of German economic performance are premised on origins from well before the second half of the twentieth century. As Figure 4 shows, Germany's share of exports in 1910 was actually greater than during the Wirtschaftswunder in 1960. Thus, Germany had already emerged as the successful export nation that it is today, right after its industrialization, a century and a half earlier.

Table I further supports the view that the German internationalization performance dates back to the country's incipience, by showing various national accounts of Germany between 1880-1979. Between 1902 and 1913 exports doubled and attained a level nearly five times higher than the value of exports in 1880. Even more striking, the value of exports only attained the 1913 peak again (before the First World War) by 1960, after the Wirtschaftswunder. Germany's export strong and sustained performance therefore is directly linked to the new leading industries back then, with a predominance of Hidden 


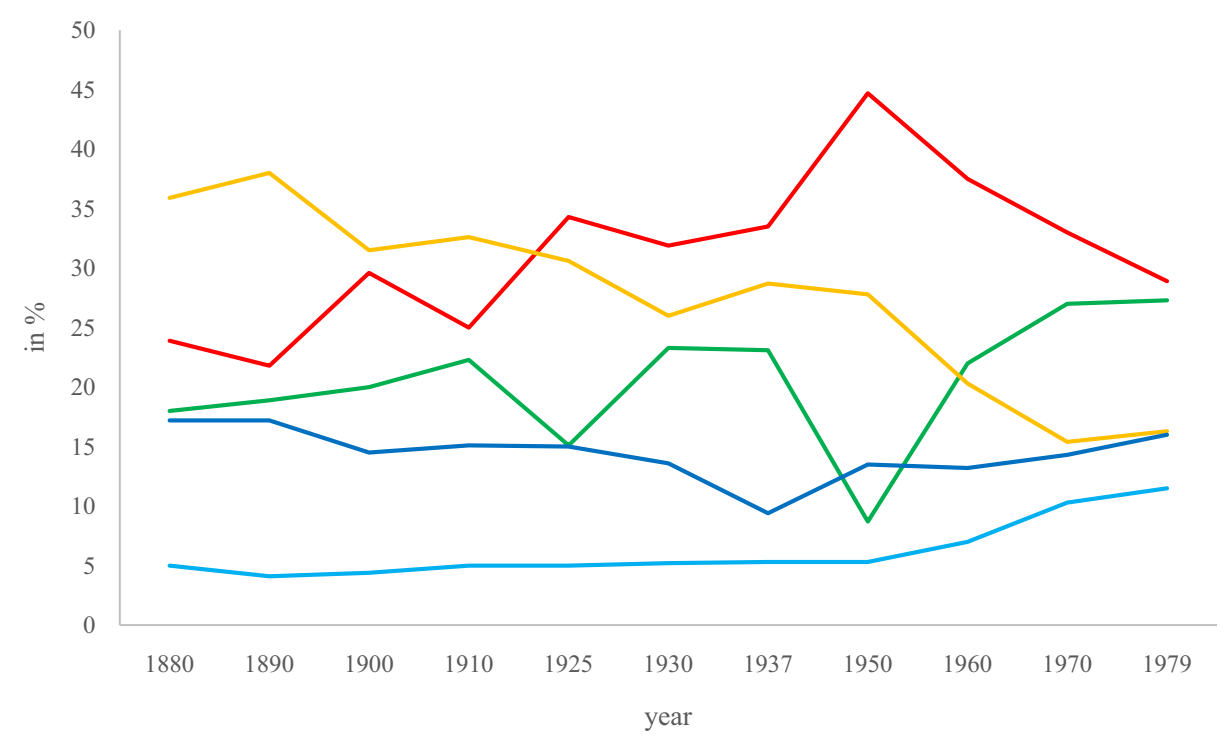

Figure 4.

Historic export shares major industrial countries (1880-1979)
Source: Own depiction following Sommariva and Tullio (1987, p. 47), data retrieved from Mitchell (1975)

Champions. The Hidden Champions contributed largely to the German rise to economic world power before First World War.

The boom in railroads and heavy industry drove German industrialization. Financing the transportation revolution, capital markets grew rapidly, resulting in a denser network of railroad lines, which in turn enabled access to regional markets along with increased demand for the production of coal and steel. This early phase of German Industrialization eventually paved the way for other technological-driven sectors to take off. The tightly knitted bond between science and industry in industrial research laboratories generated groundbreaking innovations, inciting rapid gains in productivity and market growth of the new leading sectors, such as chemicals, electrical engineering and electronics. An example of this is the 1911 founded Kaiser-Wilhelm-Gesellschaft of which its many subunits later merged into the Max-Planck and Leibniz Institutes among others.

The sharp rise of knowledge-intensive products stands out as a main driver of the competitiveness of German products. Besides a growing population and liberalization of the economy, groundbreaking technological innovation spurred the rapidly growing German economy, which enjoyed the protection under patent law issue by the Prussian patent office since 1812. The united German Reich later passed a common patent law in 1877 (Machlup and Penrose, 1950; Streb et al., 2006). One of the many examples of beneficiaries of the protective patent laws and research spillovers was Werner von Siemen's company, which generated electricity. Thanks to the invention and break-through of electronic light and the electric engine, the German electronic industry subsequently emerged with the worldleading position around 1900 (alongside the USA). Other examples include both Nikolaus August Otto's (1876) internal combustion engines that both were used when engine-driven 


\begin{tabular}{|c|c|c|c|c|}
\hline Year & Stock of capital & Imports & Exports & NNP \\
\hline 1880 & 93.97 & 2.77 & 2.31 & 19.9 \\
\hline 1885 & 106.16 & 3.48 & 2.66 & 23.5 \\
\hline 1890 & 122.68 & 4.86 & 3.09 & 27.8 \\
\hline 1895 & 141.18 & 5.77 & 3.73 & 32.1 \\
\hline 1900 & 169.37 & 7.11 & 4.65 & 36.5 \\
\hline 1905 & 197.21 & 8.42 & 5.99 & 43.4 \\
\hline 1910 & 231.30 & 9.90 & 8.00 & 47.4 \\
\hline 1913 & 255.94 & 11.20 & 10.20 & 52.4 \\
\hline 1915 & 239.31 & 3.90 & 1.90 & 42.9 \\
\hline 1920 & 197.01 & 3.70 & 3.70 & 31.9 \\
\hline 1925 & 232.19 & 8.56 & 6.89 & 46.9 \\
\hline 1929 & 253.90 & 10.63 & 10.01 & 51.7 \\
\hline 1939 & 307.60 & 7.87 & 6.07 & 83.6 \\
\hline 1946 & 133.20 & 1.50 & 0.30 & 29.9 \\
\hline 1950 & 173.80 & 5.10 & 3.46 & 44.9 \\
\hline 1955 & 218.80 & 10.70 & 8.73 & 64.8 \\
\hline 1960 & 282.93 & 19.36 & 13.93 & 85.8 \\
\hline 1965 & 372.63 & 32.20 & 19.82 & 109.2 \\
\hline 1970 & 480.28 & 48.39 & 31.81 & 137.8 \\
\hline 1975 & 606.73 & 57.44 & 39.84 & 150.1 \\
\hline 1979 & 711.69 & 79.93 & 52.23 & 175.4 \\
\hline
\end{tabular}

Note: $\mathrm{NNP}=$ net national product

Source: Own depiction following Sommariva and Tullio (1987, p. 226); prices are in 1913 prices

Table I.

National accounts of Germany 1880-1979 (in billions of Reichsmark/ deutschmark)

vehicles from entered the market (Mokyr, 1998). Germany's chemical industry rapidly expanded, particularly in plastics (Meyer-Thurow, 1982), artificial fertilizers and pharmaceuticals, where the global share of production in chemical goods manufactured by Germany reached 90 per cent by the turn of the twentieth century (Berend and Berend, 2013). Finally, heavy industry grew drastically (Figure 5) as a result of a series of technological innovations (e.g. the Siemens-Martin process in producing steel), culminating in the advent of Krupp's stainless steel in 1912.

A "German scientific superiority in the nineteenth century" (Ben-David, 1960, p. 833) is reflected in the high number of Nobel Prizes awarded to German scientists between 19011945. Until shortly after Second World War, Germany won more Nobel Prizes than the UK, USA and Russia combined. Germany was especially successful in physics, medicine and chemistry. In physics, Germany maintained the top spot regarding the number of Nobel prizes for 47 years between 1901 and 1948. In chemistry, Germany prevailed as the global leader between 1905 and 1984 (Schmidhuber, 2010). Thus, the world's leading science and knowledge base was in place to foster manufacturing in general and in particular the chemistry, electronic and engineering sectors.

The strategies driving the export performance a century ago still prevail for the strategy underlying the contemporary German Hidden Champions. This is consistent with the high share of Hidden Champions not just in manufacturing but also in those sectors that have been thriving since emerging as the leading industries after Germany's industrial transition. For example, in 2015, 44.9 per cent of all Hidden Champions were classified as belonging to the manufacturing sector, 15.9 per cent to chemicals and 15.5 per cent to electrical engineering and electronics (Rammer and Spielkamp, 2015). In fact, mechanical engineering, chemicals, electrical engineering and electronics comprised the largest subgroups of Hidden 


\section{Figure 5.}

National shares of world manufacturing output
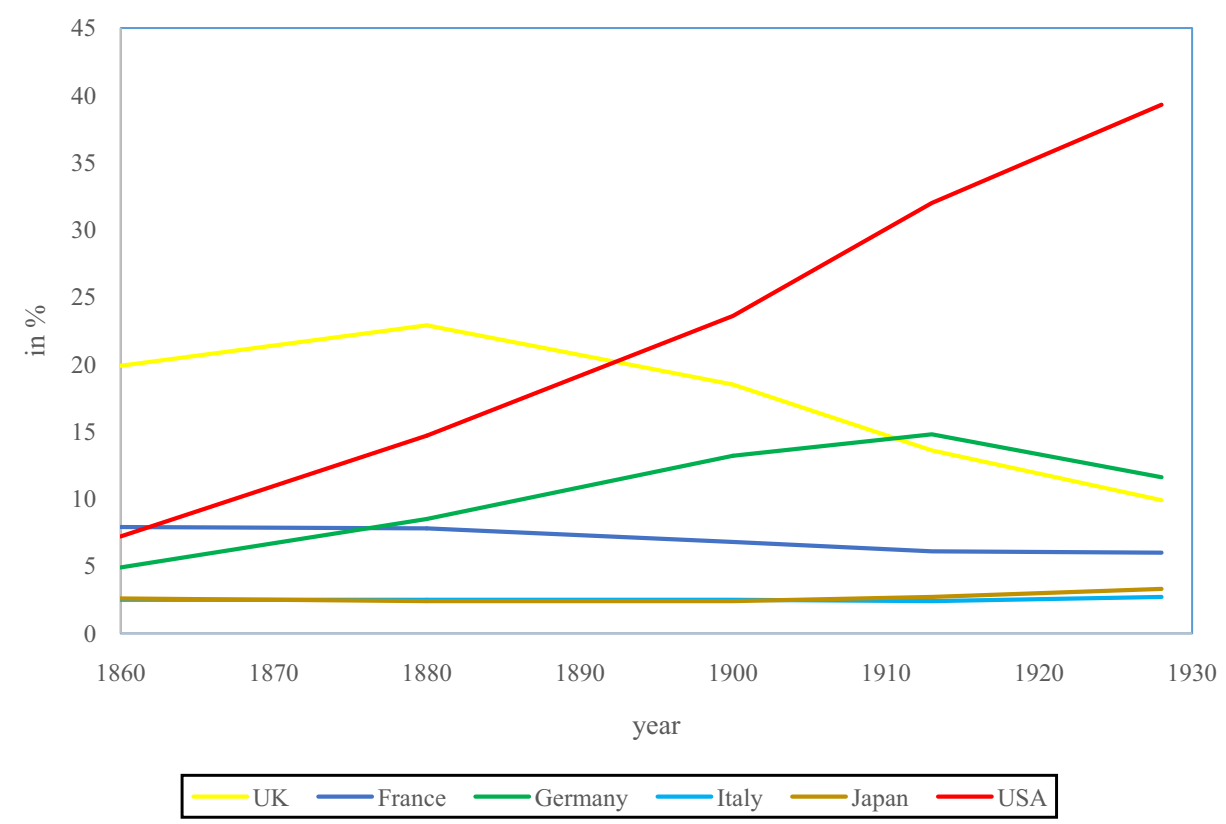

Source: Own depiction following Floud et al. (2014), data from Bairoch (1982, p. 296, 304)

Champions, suggesting a path dependence where continuity has generated a sustained performance in traditionally strong sectors, which were the same sectors serving as the major engines of Germany's industrialization.

A second country-specific source bestowing a strong and sustained international performance of the Mittelstand and German Hidden Champions is human capital in general and skilled labor in particular. The vocational education system, which includes the apprentice system (Greinert, 2005), is both specific and unique to Germany (Audretsch and Lehmann, 2016; Jahn, 2015). The apprentice system along with the other institutions facilitating worker training and skills has been identified as one of the keys to the competitiveness of the German Mittelstand (Lehmann et al., 2017). The educational vocation system in Germany reflects an institution that dates back to the system of guilds that organized vocational education.

Industrialization enabled the rise of corporations and manufacturing. The new massproduction technologies and management exerted competitive pressures on the old Mittelstand firms in the craft sector (Blackbourn, 1977). Therefore, Mittelstand policy under the German Reich between 1878-1897 provided special protections to this craft sector, the old Mittelstand, through a string of legal amendments. Wilhelm II, with the parliamentary backing of the Conservative and von Bennigsen's Nationalliberale Partei (National Liberal Party), established new chambers of craft firms with the Handwerkerschutzgesetz of 1897 ("law to protect the craft sector"), which transferred the full control of the vocational education of apprentices to the craft firms.

This early recognition of the key role played by skilled workers and the need for institutions supporting their training, explains the strength of vocational education in 
Germany, already back then. Table II shows that as early as 1910, Germany led in terms of the provision of this kind of "third-way" human capital or skilled labor, next to tertiary or high education. Thus, the human capital needs of German manufacturing and engineering firms (including the Hidden Champions) has subsequently benefitted from Germany's emphasis and strength in vocational education. Germany, along with the Scandinavian countries, exhibited especially higher literacy rates at the turn of the twentieth century (compared to South and East Europe), which was a central prerequisite for vocational education regarding the formation of specific human capital (Kaestle, 1985). It is not a coincidence that both the German speaking countries and Scandinavia exhibit the highest prevalence of Hidden Champions (Figure 1).

As Figure 6 shows, the majority of Hidden Champions (53.4 per cent) was founded prior to the end of Second World War (Simon, 2009). Thus, the same institutions underlying

\begin{tabular}{lcccc}
\hline Sector & Year & UK (high/intermediate) & Germany (high/intermediate) & USA (high/intermediate) \\
\hline Agriculture & 1910 & $-/-$ & $-/-$ & $-/-$ \\
Industry & 1910 & $-/ 15.1$ & $-/ 19.8$ & $-/ 2.8$ \\
Services & 1910 & $2.0 / 2.0$ & $2.4 / 1.6$ & $3.0 / 0.2$ \\
Agriculture & 1930 & $-/-$ & $-/-$ & $-/-$ \\
Industry & 1930 & $-/ 15.6$ & $-/ 23.7$ & $4.1 / 1.9$ \\
Services & 1930 & $2.6 / 1.5$ & $2.1 / 1.2$ & $3.5 / 0.1$ \\
Agriculture & 1950 & $-/ 0.5$ & $-/ 0.5$ & $-/-$ \\
Industry & 1950 & $5.7 / 12.9$ & $5.7 / 24.4$ & $10.5 / 1.6$ \\
Services & 1950 & $3.8 / 1.8$ & $3.1 / 3.9$ & $4.0 / 1.6$
\end{tabular}

Source: Broadberry (2003)

Table II.

Stock of vocationally qualified employees (\% of all employees)

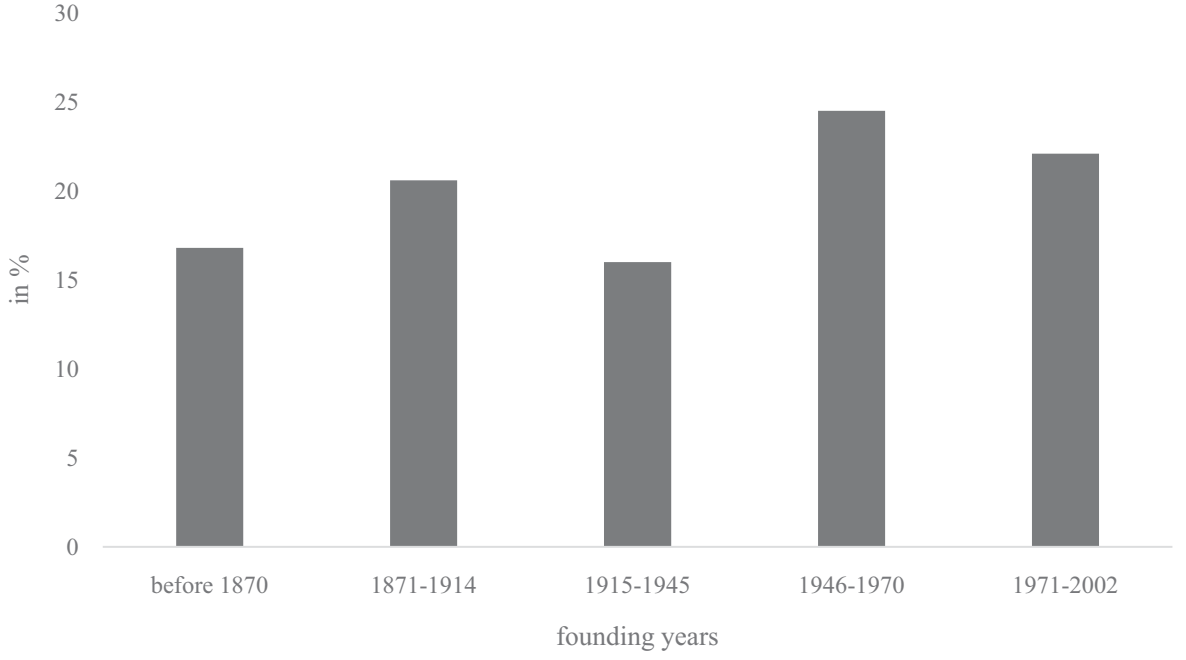

Source: Own depiction following Simon (2009, p. 21)
Figure 6. Founding years of hidden champions 
German industrialization 150 years ago also served as the catalyst for the birth and subsequent sustained of many of the Hidden Champions.

Lagging behind the industrialization process of other western countries, such as the UK, USA, Belgium and France for many decades, a unified and empowered Germany not only presented a military threat to other nations but also emerged as the leading economy in the world, which eventually served as a catalyst underlying First World War (Berend and Berend, 2013). For a long time, the UK had stood out has the cradle of industrialization and had been referred to as the Workshop of the World (Samuel, 1977). The soaring German manufacturing output prompted England in 1887 to brand imported goods from its main competitor, Germany, as Made in Germany, which was intended to cast German manufactured products as having poor quality. In fact, this move ironically only brought about a prestigious brand of high quality that continues today and instead provided a sharp contrast to goods manufactured in Britain. Warning British Customers of low quality goods manufactured in Germany had the opposite effect and instead highlighted a quality difference to the detriment of the UK. The reputation of German manufactured goods remains an obvious reflection of outstanding quality and continues to sustain a strong reputation of German manufacturing.

At least some empirical evidence supports the superior reputation of German manufacturing. For example, respondents of the Statista Survey for the Made in Country Index (2017) used a five-point Likert scale to answer the question „On a lot of products you can find a label stating where product was made. How do you feel about labeled with [. . .]?” The rank in the worldwide index is bounded as an index benchmark of 100 points. As Table III shows that not only does Germany clearly hold the top spot but also together with Switzerland and the UK, accounts for 55 per cent of all Hidden Champions worldwide. This underlines the link between quality capabilities and the ability to generate and sustain Hidden Champions.

In addition, as Table IV shows, the Deloitte (2016) Global Manufacturing Competitiveness Index ranked nations based on their manufacturing competitiveness. Germany is ranked in third place, just behind China and the USA. The global CEO survey identifies talent as the key driver to competitiveness. The country-specific institutions and policies focusing on science, human capital, worker skills and training have resulted in a relative abundance of talent in Germany, which in turn underlies the country's competitive advantage in manufacturing. Although neither of these indices directly measure the role of the Hidden Champions, their presence and impact are implied, as they play a key role in both German manufacturing and internationalization. Thus, both of these indices are consistent

Table III.

\begin{tabular}{lr}
\hline Country & Score \\
\hline Germany & 100 \\
Switzerland & 98 \\
UK & 91 \\
Sweden & 90 \\
Canada & 85 \\
Italy & 84 \\
Japan & 81 \\
France & 81 \\
USA & 81 \\
Finland & 77 \\
Source: Statista (2017) &
\end{tabular}




\begin{tabular}{lrr}
\hline Country & Score & \\
\hline China & 100.0 & \\
USA & 99.5 & \\
Germany & 93.9 & \\
Japan & 80.4 & \\
South Korea & 76.7 & \\
UK & 75.8 & \\
Taiwan & 72.9 & Table IV. \\
Mexico & 69.5 & Manufacturing \\
Canada & 68.7 & competitiveness \\
Singapore & 68.4 & index top 10 \\
Source: Deloitte (2016) & & \\
\hline
\end{tabular}

with the view that German Engineering is the source of the high-quality product niche strategy central to the Hidden Champions.

Another source of the Hidden Champions export performance is cultural. Much of the special skill set supporting technology-driven products dates back to typical PrussianGerman virtues that spread from the former parts of the North German Confederation (Norddeutscher Bund) throughout the rest of Germany following the Lesser German solution, when Prussia took the lead in the German Reich. Among these virtues, discipline, determination, diligence and toughness stand out (Dorn, 1931; Veblen, 1990) and are also partly based on the Puritan work ethos that Max Weber described in his seminal 1905 book, The Protestant Ethic and the Spirit of Capitalism (Weber, 1930; Becker and Woessmann, 2011). Support of the key role played by the meaning of culture is provided from a survey of 220 German Mittelstand firms revealing that the four most important human qualities for what is crucial to their success are precision, innovativeness, technical expertise and longevity of planning (PWC, 2017). These attributes are key characteristics exhibited by the German Mittelstand (Audretsch and Lehmann, 2016).

In particular, the model of the German Mittelstand reflects a core set of traditional values: long-term orientation of planning and decision-making (Le Breton-Miller and Miller, 2006), which results in agency cost minimizing owner-management (Schulze et al., 2001). Similarly, the Mittelstand values long-turn sustainability that is lasting and preserves the owner's name and family through internal succession. To extend their legacy beyond their working career, family business owners tend to treat profitability as a long-run rather than a short-run goal. Finally, the German Mittelstand as bearer of Prussian-German Virtues generally exhibits both thoroughness and precision. As they are a subset of the Mittelstand, the superior product quality and strong internationalization performance of the German Hidden Champions reflect those cultural virtues. The long-term orientation is especially conducive to developing a viable knowledge base and continually improving the product, particularly in manufacturing (Le Breton-Miller and Miller, 2006). In addition, the cultural values of meticulous and precise work ascribed to the German Mittelstand is conducive to the technological intensive products manufactured by the Hidden Champions.

This very formation of the German Mittelstand as epitome of the German Engineering model also dates back to the middle of the twentieth century, when the traditional handcraft firms became outdated. With the old handcraft-based Mittelstand diminishing by half after 1880, industrialization triggered the emergence of a new type of Mittelstand citizens ranging 
from upper-middle class industrial managers from the so-called Bourgeoisie on the one hand and ordinary employees from the (educated) middle-class on the other.

Leadership played a core role in shaping the institutions central to the Hidden Champions strong economic and export performance. In particular, the Chancellor of the country, Otto von Bismarck, to sustain social cohesion, recognized the need to win the support of a broad spectrum spanning disparate elements of society, ranging from the nobility, the bourgeoisie to a mostly social democratic-oriented proletariat. The contemporary view that the Mittelstand provides the backbone of German economy dates back to the German Empire of 1871, when first von Bismarck and subsequently Wilhelm II both wisely foresaw the necessity of supporting the Mittelstand as the backbone of a stable monarchy (Blackbourn, 1977; Abrams, 2007).

The new Mittelstand citizens found their way to German society through the rise of the new corporate centered industrial landscape of firms that offered plenty of jobs in business administration, commerce, banks and insurance. The old Mittelstand (handcraft) gradually developed their businesses around the niches of newly pioneered technological innovations, shifting from former mostly textile-driven to metal processing and mechanical engineering businesses, which fueled the birth of many Hidden Champion firms.

To conclude this section on Germany's role as the home country of Hidden Champion, Simon (2012) posited another hypothesis of why Germany exhibits such a strong internationalization performance in general and export success in particular. He argues that Germany's historic Kleinstaaterei (which translates as German particularism) forces German firms to engage in international transactions more frequently when exporting to other countries than when trading between Prussia, Wurttemberg or Hanover. While this argument provides some insight, it overlooks a key source that benefitted the Mittelstand and Germany's Hidden Champions. Simon (2012) overlooks the key role played by the German Customs Union (Zollverein). Reviewing the full original contract of March 22, 1833, the Zollverein provides a mandate that free trade for business transactions was to be organized in a united customs union, erasing almost all trade barriers. Still Simon's (2012) argument of an early tradition of transnationally trade (Simon, 2012) may at least partially hold when considering that the 1865 Commercial (Handelsgesetzbuch) and 1900 Civil Code (Bürgerliches Gesetzbuch), along with a common currency, weights and measures were not introduced nationwide until the founding of the Reich in 1871.

However, it is even more important to emphasize that a virtually free trade zone lowered transaction costs, enabling greater economies of scale in production. Other arguments raised by Simon (2012) include above average English language proficiency skills, high rates of incoming and outgoing students and tourism to shape a German global awareness, which in turn contributed to internationalization activities more naturally (Hejazi and Ma, 2011). Again, these arguments do not explain the German export success prior to First World War around 1900. English as foreign language was introduced as a compulsory language in secondary schools (Haupt- and Realschule) only as recently as 1964 (Christ and Rang, 1985). Graduates from the Haupt-and Realschule generally pursue careers in vocational education and comprised a large share of the workforce employed by Hidden Champions. Thus, Simon's argument of language proficiency does not hold importance. In addition, it should also be noted that neither mass tourism nor large-scale student exchanges became prevalent prior to the 1960s. Therefore, there must be more than Simon's (2012) explanation attributing foreign language proficiency, tourism and student exchanges to the strong 
internationalization activities exhibited by the Mittelstand in general and the Hidden Champions in particular.

\section{Conclusion}

The Hidden Champions of Germany present an anomaly to the more general findings in a burgeoning literature finding that SMEs have a low propensity to internationalize. This paper has shed light not just on why the Hidden Champions provide an exception to the rule of a paucity of internationalization activities but also how and why the home country of Germany is particularly conducive to developing and sustaining Hidden Champions (Rammer and Spielkamp, 2015). This paper is the first to link the success of Germany's Hidden Champions to the historic origins of its Mittelstand model and the transition of economic sectors in the second half of the nineteenth century.

The high degree of internationalization exhibited by the Hidden Champions mirrors their core strategy. In particular, the strategic priority of manufacturing high quality premium products to dominate market niches requires geographic expansion in narrowly defined market niches across national borders.

Germany has proven to be a particularly fertile home country generating and fostering Hidden Champions because of the historical and traditional institutions, along with policies focusing on creating and sustaining a highly skilled labor force. The relative abundance of highly skilled labor, together with investments in science and technology is conducive to the key inputs requisite to a sustained competitive advantage of the Mittelstand in general and the Hidden Champions in particular.

The German Mittelstand along with its subset of Hidden Champions provides a seductive model for policymakers throughout the world. However, an important conclusion of this paper is that the strong and sustained export and internationalization performance of the Mittelstand and Hidden Champions are rooted in institutions and polices dating back to the Middle Ages. Whether contemporary policies in other countries can synthetically emulate institutions and values that are historically rooted in a different national context remains an important and open question for further research.

\section{Note}

1. The coalition of rye and iron is an established term that points to the alliance of both industrial and agrarian interest groups with regard to protective tariffs.

\section{References}

Aaby, N.E. and Slater, S.F. (1989), "Management influences on export performance: a review of the empirical literature 1978-1988", International Marketing Review, Vol. 6 No. 4, pp. 7-26.

Abrams, L. (2007), Bismarck and the German Empire: 1871-1918, Routledge, New York, NY.

Acemoglu, D., Griffith, R., Aghion, P. and Zilibotti, F. (2010), "Vertical integration and technology: theory and evidence", Journal of the European Economic Association, Vol. 8 No. 5, pp. 989-1033.

Acs, Z., Audretsch, D.B., Lehmann, E.E. and Licht, G. (2016), "National systems of entrepreneurship", Small Business Economics, Vol. 46 No. 4, pp. 527-535.

Acs, Z., Audretsch, D.B., Lehmann, E.E. and Licht, G. (2017), “National systems of innovation”, Journal of Technology Transfer, Vol. 42 No. 5, pp. 997-1008.

Antràs, P. and Chor, D. (2013), "Organizing the global value chain”, Econometrica, Vol. 81 No. 6, pp. 2127-2204. 
Antràs, P. and Helpman, E. (2004), "Global sourcing”, Journal of Political Economy, Vol. 112 No. 3, pp. 552-580.

Audretsch, D.B. and Lehmann, E.E. (2016), The Seven Secrets of Germany: Economic Resilience in an Era of Global Turbulence, Oxford University Press, New York.

Audretsch, D.B., Prince, Y.M. and Thurik, A.R. (1999), "Do small firms compete with large firms?", Atlantic Economic Journal, Vol. 27 No. 2, pp. 201-209.

Bairoch, P. (1982), "International industrialization levels from 1750 to 1980", Journal of European Economic History, Vol. 11 No. 2, pp. 269-333.

Becker, G.S. (1964), Human Capital: A Theoretical and Empirical Analysis, with Special Reference to Education, Chicago University Press, Chicago, IL.

Becker, S.O. and Woessmann, L. (2011), "The effects of the protestant reformation on human capital", in McCleary, R.M. (Ed.), The Oxford Handbook of the Economics of Religion, Oxford University Press, Oxford, pp. 93-110.

Ben-David, J. (1960), "Scientific productivity and academic organization in nineteenth century medicine", American Sociological Review, Vol. 25 No. 6, pp. 828-843.

Berend, I. and Berend, T.I. (2013), An Economic History of Nineteenth-Century Europe: Diversity and Industrialization, Cambridge University Press, Cambridge.

Berger, S. (1995), "Historians and nation-building in Germany after reunification", Past and Present, Vol. 148 No. 1, pp. 187-222.

Blackbourn, D. (1977), "The Mittelstand in German society and politics, 1871-1914", Social History, Vol. 2 No. 4, pp. 409-433.

Blackburn, J., Merrilees, B., Tiessen, J. and Lindman, M. (2001), "Hidden (SME) champions: the role of innovation and strategy", paper presented at Proceedings of the Australian and New Zealand Marketing Academy Conference, 1-5 December 2001.

Blackstone, B. and Fuhrmans, V. (2011), "The engines of growth: forget the big global brands, Germany's economy is powered by a legion of smaller companies", Wall Street Journal, June 27, 2011, available at: www.wsj.com/articles/SB10001424052748703509104576329643153915516 (accessed 22 March 2017).

Bonaccorsi, A. (1992), "On the relationship between firm size and export intensity", Journal of International Business Studies, Vol. 23 No. 4, pp. 605-635.

Bourgeois, L.J. (1981), "On the measurement of organizational slack", Academy of Management Review, Vol. 6 No. 1, pp. 29-39.

Broadberry, S.N. (2003), "Human capital and productivity performance: Britain, the United States and Germany, 1870-1990", in David, P.A. and Thomas, M. (Eds), The Economic Future in Historical Perspective, The British Academy and Oxford University Press, Oxford, pp. 103-133.

Burton, E.N. and Schlegelmilch, B.B. (1987), "Profile analysis of non-exporters versus exporters grouped by export involvement", International Management Review, Vol. 27 No. 1, pp. $38-49$.

Cavusgil, S.T. (1984), "Differences among exporting firms based on their degree of internationalization", Journal of Business Research, Vol. 12 No. 2, pp. 195-208.

Cavusgil, S.T. and Zou, S. (1994), "Marketing strategy-performance relationship: an investigation of the empirical link in export market ventures", The Journal of Marketing, Vol. 58 No. 1, pp. 1-21.

Chetty, S.K. and Hamilton, R.T. (1993), "Firm-level determinants of export performance: a Metaanalysis", International Marketing Review, Vol. 10 No. 3, pp. 26-34.

Christ, H. and Rang, H.-J. (1985), Fremdsprachenunterricht Unter Staatlicher Verwaltung 1700-1945, Gunter Narr, Tübingen.

Coviello, N.E. and McAuley, A. (1999), "Internationalization and the smaller firm: a review of contemporary empirical research", MIR: Management International Review, Vol. 39 No. 3, pp. 223-256. 
Cunningham, M.T. and Spiegel, R.I. (1971), “A study in successful exporting”, European Journal of Marketing, Vol. 5 No. 1, pp. 2-12.

Dalgic, T. and Leeuw, M. (1994), "Niche marketing revisited: concept, applications and some European cases", European Journal of Marketing, Vol. 28 No. 4, pp. 39-55.

Deloitte (2016), "2016 global manufacturing competitiveness index", available at www2.deloitte. $\mathrm{com} / \mathrm{global} / \mathrm{en} / \mathrm{pages} / \mathrm{manufacturing} /$ articles/global-manufacturing-competitiveness-index.html (accessed 9 December 2017).

Demsetz, H. (1988), "The theory of the firm revisited", Journal of Law, Economics, and Organization, Vol. 4 No. 1, pp. 141-161.

Dorn, W.L. (1931), "The Prussian bureaucracy in the eighteenth century", Political Science Quarterly, Vol. 46 No. 3, pp. 403-423.

Dunning, J.H. (1988), "The eclectic paradigm of international production: a restatement and some possible extensions", Journal of International Business Studies, Vol. 19 No. 1, pp. 1-31.

Fariborzi, H. and Keyhani, M. (2017), "Internationalization to live: a study of the postinternationalization survival of new ventures", Small Business Economics, Vol. 50 No. 3, pp. 607-624, available at: https://link.springer.com/article/10.1007/s11187-017-9910-6 (accessed 18 January 2017).

Fearon, J.D. (1999), "What is identity (as we now use the word)", working paper, Stanford University, Stanford, CA.

Fernández, Z. and Nieto, M.J. (2005), "Internationalization strategy of small and medium-sized family businesses: some influential factors", Family Business Review, Vol. 18 No. 1, pp. 77-89.

Floud, R., Humphries, J. and Johnson, P. (2014), The Cambridge Economic History of Modern Britain, Cambridge University Press, Cambridge, Industrialization, Vol. 1, pp. 1700-1870.

Francioni, B., Pagano, A. and Castellani, D. (2016), "Drivers of SMEs' exporting activity: a review and a research agenda", Multinational Business Review, Vol. 24 No. 3, pp. 194-215.

Gómez-Mejía, L.R., Haynes, K.T., Núñez-Nickel, M., Jacobson, K.J. and Moyano-Fuentes, J. (2007), "Socioemotional wealth and business risks in family-controlled firms: evidence from Spanish olive oil mills", Administrative Science Quarterly, Vol. 52 No. 1, pp. 106-137.

Graves, C. and Thomas, J. (2008), "Determinants of the internationalization pathways of family firms: an examination of family influence", Family Business Review, Vol. 21 No. 2, pp. 151-167.

Greinert, W.-D. (2005), Mass Vocational Education and Training in Europe: Classical Models of the 19th Century and Training in England, France and Germany during the First Half of the 20th, Office for Official Publications of the European Communities, CEDEFOP Panorama, Luxemburg.

Grossman, S.J. and Hart, O. (1986), "The costs and benefits of ownership: a theory of vertical and lateral integration", Journal of Political Economy, Vol. 94 No. 4, pp. 691-719.

Harris, D., Martinez, J.I. and Ward, J.L. (1994), "Is strategy different for the family-owned business?", Family Business Review, Vol. 7 No. 2, pp. 159-174.

Hejazi, W. and Ma, J. (2011), "Gravity, the English language and international business", Multinational Business Review, Vol. 19 No. 2, pp. 152-167.

Hoffmann, W.G. (1965), Das Wachstum Der Deutschen Wirtschaft Seit Der Mitte Des 19. Jahrhunderts, Springer-Verlag, Heidelberg.

Holmström, B.R. and Tirole, J. (1989), "The theory of the Firm”, in Schmalensee, R. and Willig, R. D. (Eds), Handbook of Industrial Organization, North-Holland, Amsterdam, Vol. 1, pp. 61-133.

Holzmuller, H.H. and Kasper, H. (1991), "On a theory of export performance: personal and organizational determinants of export trade activities observed in small and medium-sized firms", Management International Review, Vol. 31, pp. 45-70. 
Jahn, V. (2015), "The importance of Mittelstand firms for regional apprenticeship activity - lessons for policy”, Helmut Schmidt University, Working Paper Series No. 158.

Johanson, J. and Vahlne, J.E. (1977), "The internationalization process of the firm-a model of knowledge development and increasing foreign market commitments", Journal of International Business Studies, Vol. 8 No. 1, pp. 23-32.

Julian, C.C. (2003), "Export marketing performance: a study of Thailand firms", Journal of Small Business Management, Vol. 41 No. 2, pp. 213-221.

Kaestle, C.F. (1985), "Chapter 1: the history of literacy and the history of readers", Review of Research in Education, Vol. 12 No. 1, pp. 11-53.

Katsikeas, C.S. and Morgan, R.E. (1994), "Differences in perceptions of exporting problems based on firm size and export market experience”, European Journal of Marketing, Vol. 28 No. 5, pp. 17-35.

Kirpalani, V.H. and Macintosh, N.B. (1980), "International marketing effectiveness of technologyoriented small firms", Journal of International Business Studies, Vol. 11 No. 3, pp. 81-90.

Koed Madsen, T. (1989), "Successful export marketing management: some empirical evidence", International Marketing Review, Vol. 6 No. 4.

Kotler, P. (1991), "From mass marketing to mass customization”, Planning Review, Vol. 17 No. 5, pp. 11-47.

Lages, L.F., Silva, G. and Styles, C. (2009), "Relationship capabilities, quality, and innovation as determinants of export performance", Journal of International Marketing, Vol. 17 No. 4, pp. 47-70.

Le Breton-Miller, I. and Miller, D. (2006), "Why do some family businesses out-compete? Governance, long-term orientations, and sustainable capability”, Entrepreneurship Theory and Practice, Vol. 30 No. 6, pp.731-746.

Lehmann, E.E., Schenkenhofer, J. and Wirsching, K. (2017), "main street entrepreneurship and hidden champions: a question of the context of human capital investment", working paper, University of Augsburg, Augsburg.

Leonidou, L.C. (1995), “Export barriers: non-exporters' perceptions”, International Marketing Review, Vol. 12 No. 1, pp. 4-25.

Leonidou, L.C., Katsikeas, C.S. and Samiee, S. (2002), "Marketing strategy determinants of export performance: a Meta-analysis", Journal of Business Research, Vol. 55 No. 1, pp. 51-67.

Levy, O., Beechler, S., Taylor, S. and Boyacigiller, N.A. (2007), "What we talk about when we talk about 'global mindset': managerial cognition in multinational corporations", Journal of International Business Studies, Vol. 38 No. 2, pp. 231-258.

Lileeva, A. and Van Biesebroeck, J. (2008), "Outsourcing when investments are specific and complementary”, National Bureau of Economic Research, NBER Working Paper No. 14477.

McDonald, F., Warhurst, S. and Allen, M. (2008), "Autonomy, embeddedness, and the performance of foreign owned subsidiaries", Multinational Business Review, Vol. 16 No. 3, pp. 73-92.

Machlup, F. and Penrose, E. (1950), "The patent controversy in the nineteenth century", The Journal of Economic History, Vol. 10 No. 1, pp. 1-29.

Majocchi, A., Bacchiocchi, E. and Mayrhofer, U. (2005), "Firm size, business experience and export intensity in SMEs: a longitudinal approach to complex relationships", International Business Review, Vol. 14 No. 6, pp. 719-738.

Meyer-Thurow, G. (1982), "The industrialization of invention: a case study from the German chemical industry", Isis, Vol. 73 No. 268, pp. 3, pp. 363-381.

Michell, P. (1979), "Infrastructure and international marketing effectiveness", Columbia Journal of World Business, Vol. 14, pp. 91-101.

Mitchell, B.R. (1975), European Historical Statistics 1750-1970, Columbia University Press, New York, NY. 
Mokyr, J. (1998), "The second industrial revolution, 1870-1914", in Castronono, V. (Ed.), Storia Dell'economia Mondiale, Laterza Publishing, Rome, pp. 219-245.

Morgan, N.A., Kaleka, A. and Katsikeas, S.C. (2004), "Antecedents of export venture performance: a theoretical model and empirical assessment”, Journal of Marketing, Vol. 68 No. 1, pp. 90-108.

Nelson, R.R. (1993), National Systems of Innovation: A Comparative Analysis, Oxford University Press, Oxford.

Nummela, N., Saarenketo, S. and Puumalainen, K. (2004), "A global mindset-a prerequisite for successful internationalization?”, Canadian Journal of Administrative Sciences, Vol. 21 No. 1, pp. 51-64.

Nunn, N. and Trefler, D. (2008), "The boundaries of the multinational firm: an empirical analysis," in Helpman, E., Marin D. and Verdier T. (Eds), The Organization of Firms in a Global Economy, Harvard University Press, Cambridge, pp. 55-83.

OECD (2017), "Exports by business size (indicator)", available at https://data.oecd.org/trade/exportsby-business-size.htm (accessed 6 December 2017).

Porter, M.E. (1980), Competitive Strategy: Techniques for Analyzing Industries and Competitors, The Free Press, New York, NY.

PWC (2017), "Potenzialanalyse: wie digital sind die deutschen Mittelständler?", available at www.pwc. de/de/mittelstand/assets/digitalisierungsbefragung-21122016-auskopplung.pdf (accessed 9 December 2017).

Rammer, C. and Spielkamp, A. (2015), "Hidden champions - driven by innovation", ZEW Mannheim Dokumentation.

Ramsey, J.R., Abi Aad, A., Jiang, C., Barakat, L. and Drummond, V. (2016), "Emergence of cultural intelligence and global mindset capital: a multilevel model", Multinational Business Review, Vol. 24 No. 2, pp. 106-122.

Samuel, R. (1977), "The workshop of the world: steam power and hand technology in Mid-Victorian Britain", History Workshop Journal, Vol. 3 No. 1, pp. 6-72.

Schlepphorst, S., Schlömer-Laufen, N. and Holz, M. (2016), "Determinants of hidden champions: evidence from Germany", working paper, Institut für Mittelstandsforschung (IfM), Bonn.

Schmidhuber, J. (2010), "Evolution of national Nobel prize shares in the 20th century", available at www.idsia.ch/ juergen/nobelshare.html (accessed 10 December 2017).

Schulze, W.S., Lubatkin, M.H., Dino, R.N. and Buchholtz, A.K. (2001), "Agency relationships in family firms: theory and evidence”, Organization Science, Vol. 12 No. 2, pp. 99-116.

Simon, H. (2009), Hidden Champions of the 21st Century: Success Strategies of Unknown Market Leaders, Springer-Verlag, Heidelberg.

Simon, H. (2012), Hidden Champions-Aufbruch Nach Globalia: Die Erfolgsstrategien Unbekannter Weltmarktführer, Campus Verlag, Frankfurt am Main.

Sommariva, A. and Tullio, G. (1987), German Macroeconomic History 1880-1979, McMillan, London.

Stanton, W.E.J., Etzel, M.J. and Walker, B.J. (1991), Fundamentals of Marketing, McGraw-Hill, New York, NY.

Statista (2017), "Made-In-Country-Index", available at www.statista.com/page/Made-In-Country-Index (accessed 9 December 2017).

Streb, J., Baten, J. and Yin, S. (2006), "Technological and geographical knowledge spillover in the German empire 1877-1918”, The Economic History Review, Vol. 59 No. 2, pp. 347-373.

The Economist (2014), "German lessons: most countries want a Mittelstand like Germany's," The Economist, July 12, 2014, available at: www.economist.com/news/business/21606834-manycountries-want-mittelstand-germanys-it-not-so-easy-copy-german-lessons (accessed 22 March 2017). 
Torp, C. (2010), "The coalition of 'rye and iron' under the pressure of globalization: a reinterpretation of Germany's political economy before 1914", Central European History, Vol. 43 No. 3, pp. 401-427.

Veblen, T. (1990), Imperial Germany and the Industrial Revolution, Transaction Publishers, NJ.

Venohr, B. and Meyer, K.E. (2007), "The German miracle keeps running: how Germany's hidden champions stay ahead in the global economy", working paper, Institute of Management Berlin, Berlin School of Economics (FHW Berlin).

Verbeke, A. and Yuan, W. (2016), "The impact of distance on multinational enterprise subsidiary capabilities: a value chain perspective”, Multinational Business Review, Vol. 24 No. 2, pp. 168-190.

Weber, M. (1930), The Protestant Ethic and the Spirit of Capitalism: Translated from the German, in Parsons, T. (Ed.), Scribner's, New York, NY.

Weisbrod, B. (1996), “German unification and the national paradigm”, German History, Vol. 14 No. 2, pp. 193-203.

Welter, F., Levering, B. and May-Strobl, E. (2016), "Mittelstandspolitik im Wandel”, IfM Bonn: IfM Materialien Nr, Bonn, p. 247.

Westhead, P., Wright, M. and Ucbasaran, D. (2001), "The internationalization of new and small firms: a resource-based view", Journal of Business Venturing, Vol. 16 No. 4, pp. 333-358.

Williamson, O.E. (1975), Markets and Hierarchies, Analysis and Antitrust Implications, Simon \& Schuster, New York.

Witt, A. and Carr, C. (2014), "Success secrets shared: learning from the best Mittelstand and British global niche champions", Scottish Policy Now, 8. available at: www.scottishpolicynow.co.uk/ issues/

Yoon, B. (2013), "How do hidden champions differ from normal small and medium enterprises (SMEs) in innovation activities?", Journal of Applied Sciences Research, Vol. 9 No. 13, pp. 6257-6263.

Zahra, S.A. (2003), "International expansion of US manufacturing family businesses: the effect of ownership and involvement", Journal of Business Venturing, Vol. 18 No. 4, pp. 495-512.

Zou, S. and Stan, S. (1998), "The determinants of export performance: a review of the empirical literature between 1987 and 1997”, International Marketing Review, Vol. 15 No. 5, pp. 333-356.

Zuchella, A. and Palamara, G. (2006), "Niche strategy and export performance", Advances in International Marketing, Vol. 17 No. 1, pp. 63-87.

\section{Further reading}

Hart, O. (1988), "Incomplete contracts and the theory of the firm", Journal of Law, Economics, and Organization, Vol. 4 No. 1, pp. 119-139.

Hart, O. and Moore, J. (1990), "Property rights and the nature of the firm", Journal of Political Economy, Vol. 98 No. 6, pp. 1119-1158.

Meyer, K. (2017), "International business in an era of anti-globalization”, Multinational Business Review, Vol. 25 No. 2, pp. 78-90.

\section{Corresponding author}

David B. Audretsch can be contacted at: daudrets@indiana.edu 